\title{
Stochastic Prediction of Drought Class Transitions
}

\author{
Ana A. Paulo • Luis S. Pereira
}

Received: 11 January 2007 / Accepted: 22 October 2007 /

Published online: 18 December 2007

(C) Springer Science + Business Media B.V. 2007

\begin{abstract}
This paper aims at the stochastic characterization of droughts applying Markov chains modeling to drought class transitions derived from SPI time series. Several sites in Southern Portugal having updated data on precipitation available were considered. The drought class probabilities, the expected residence time in each class of severity, the expected time for the transition between drought classes and the drought severity class predictions 1, 2, or 3 months ahead have been obtained. Those predictions are then compared with observed drought classes for the recent drought periods of 2003-2006. In addition, the estimation of the cumulated precipitation deficits, amount of monthly precipitation needed to decrease drought severity, and foreseen SPI values depending on different precipitation scenarios are also presented as complementing the prediction of drought class transitions.
\end{abstract}

Keywords Markov chains $\cdot$ Standardized Precipitation Index $\cdot$ Stochastic modeling · Rainfall deficits $\cdot$ Portugal

\section{Introduction}

A better understanding of droughts is essential to develop tools for prediction or forecasting of drought initiation and ending, as well as the evolution of its severity, so that these occurrences may be clearly recognized. Droughts have a slow initiation and they are usually only recognised when the drought is already established. They are of long duration, and usually affect large areas. Their impacts are pervasive. Forecasting of when a drought is likely to begin or to come to an end is extremely difficult (NDMC 2006). An adequate lead-time is often more important than the accuracy of the prediction. The lead-time makes it possible for decision and policy makers to timely implement policies and measures to mitigate the effects of drought (Buchanan-Smith 2000; Sivakumar and Wilhite 2002; Rossi 2003;

A. A. Paulo • L. S. Pereira $(\bowtie)$

Agricultural Engineering Research Center, Institute of Agronomy, Technical University of Lisbon, Lisbon, Portugal

e-mail: Lspereira@isa.utl.pt 
Tsakiris and Vangelis 2004). The less predictable characteristics of droughts with respect to their initiation and termination, frequency and severity make it important drought monitoring and to improve the stochastic characterization of droughts aiming at early warning

Drought monitoring includes the monitoring of precipitation, the primary cause of droughts, as well as river flow and water storage levels. Drought indices derived from precipitation or from other climatic and hydrological variables are usually used to assess the evolution of drought severity. The Standardized Precipitation Index (SPI) has become a worldwide tool in drought monitoring. The SPI is also often adopted in the Mediterranean area (Bonaccorso et al. 2003; Tsakiris and Vangelis 2004; Vicente-Serrano 2006). Following previous studies on local and regional characterization of droughts in Alentejo, where several drought indicators were tested, namely the SPI, the Palmer Drought Severity Index (PDSI) and the theory of runs, the SPI showed its superiority for the purpose of drought monitoring (Paulo et al. 2003, Paulo and Pereira 2006). In addition, SPI drought class transitions for the same region were successfully studied using Loglinear modeling (Moreira et al. 2006).

Research on drought forecasting and drought prediction includes the study of weather systems, teleconnections and global circulation models relating drought episodes with El Niño-Southern Oscillation (ENSO) phenomenon (Cordery and McCall 2000; Tadesse et al. 2005; Kim et al. 2006), with the North Atlantic Oscillation (Wedgbrow et al. 2002) or with both ENSO and local North Atlantic Sea Surface Temperature forcing (Lloyd-Hughes 2002). The empirical and statistical relationships between precipitation and surface temperature anomalies and seasonal rainfall (Cordery 1999) are also important prediction tools as well as the use of forecasts based on precipitation probabilities (Steinemann 2006) aiming at the improvement of water management and timely drought responses.

Atmospheric circulation patterns governing wet and dry rainfall regimes in Portugal are quite complex (Trigo et al. 2004; Santos et al. 2005) and although there is a potential for its exploration for drought prediction at the moment this task is difficult; however, conditions determining drought events are well known (Santos et al. 2007).

The Markov chain approach was applied to time series of the Palmer Index for early warning aimed at drought management (Lohani and Loganathan 1997; Lohani et al. 1998). Steinemann (2003) evaluated some drought indices with a multistate Markov model and observed that there were differences among the performance of the drought indicators and their trigger thresholds, which can influence drought responsive measures; however, this author did not use Markov chains for predicting drought severity. Cancelliere and Salas (2004) used a Markov chains approach to study drought length properties. These studies show that a stochastic approach may be useful for short term prediction and early warning as analyzed in previous studies (Paulo et al. 2005; Paulo and Pereira 2007).

The SPI can be computed in different time scales, which reflect the memory of the precipitation anomalies. Longer time scales are more appropriate for identifying the persistence of dry periods and analyze the impact of precipitation deficits on the water resources of a region. For this reason, the 12-month time scale was selected. The behavior of SPI time series in selected sites was analyzed focusing the transitions between drought categories; Markov chains and loglinear modeling have been applied attempting the prediction of drought class transitions of SPI (Paulo et al. 2005).

Portugal has recently faced one of the most severe droughts of the last 100 years, which had its on-set by the beginning of 2004. Following the study reported by Paulo and Pereira (2007), Markov chains modeling was applied to predict drought class transitions during that drought event, along with precipitation deficit estimation and the evaluation of drought evolution considering different scenarios of future monthly precipitation. This application is described herein and main results are presented. 


\section{Data}

The Southern regions of Portugal (Alentejo and Algarve) have a typical Mediterranean precipitation pattern, with rainfall concentration during the autumn and winter months, and a very dry summer. The 67-year monthly precipitation from 49 rainfall stations in the region of Alentejo concerning the period 1931/1932-1998/1999 and averaged by the respective area of influence is shown in Fig. 1.

The selection of the stations used for the present study is based on two criteria: updated precipitation data availability and record length. Only 14 rainfall stations in Alentejo and Algarve regions with on-line available and updated data fill those criteria. The location of all rainfall stations available on line (http://snirh.inag.pt) and updated daily is presented on the left side map (Fig. 2a); the map on the right presents the delimitation of the southern regions of Alentejo and Algarve and the location and codes of the rainfall stations utilized (Fig. 2).

The geographical coordinates and the altitude of the stations and some characteristics of the annual rainfall reported to the hydrological year (October to September) concerning the period ending in 1998/1999 are presented in Table 1.

The SPI index in a 12-month time scale has been obtained for each station from the beginning date in Table 1 until May 2006. The parameters for the computation of the SPI and for the Markov chain modeling were estimated for each time series from October of the year identified in Table 1 until September 1998/99. Methodologies for analysis of data are described by Paulo et al. (2003, 2005).

In Alentejo, the SPI relative to 49 sites and the area affected by each drought class is used to derive monthly time series of regional drought severity as defined by Paulo and Pereira (2006). The regional drought severity is computed considering the drought severity in every site and variable thresholds relative to the area under a given severity. The regional drought severity is classified as:

(a) Extreme if the areal coverage of SPI $\leq-2$ is larger than $20 \%$ of the area of the region;

(b) Severe if the areal coverage of SPI $\leq-1.5$ affects at least $30 \%$ of the total area;

(c) Moderate if the areal coverage of SPI $\leq-1$ affects at least $40 \%$ of the area; and

(d) Mild if the areal coverage of SPI $<0$ exceeds the critical areal threshold of $50 \%$.

In addition, adopting a regional drought severity relative to a more severe drought class implies that the conditions for classification in a less severe drought category are also fulfilled. In this application, the area of influence of each site was obtained from Thiessen polygons.

Fig. 1 Monthly mean areal precipitation in Alentejo (1931/ 1932 to $1998 / 1999$ )

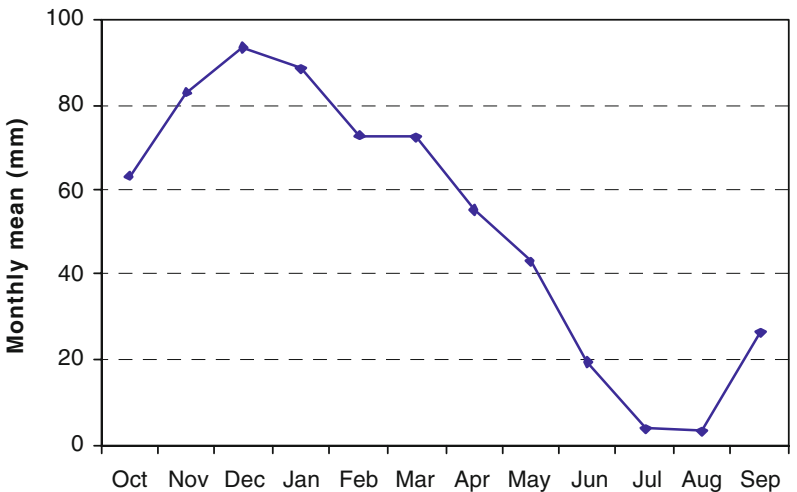


Fig. 2 a Portugal: stations with precipitation data available on line (INAG) and $\mathbf{b}$ location and code of the stations in Alentejo and Algarve regions
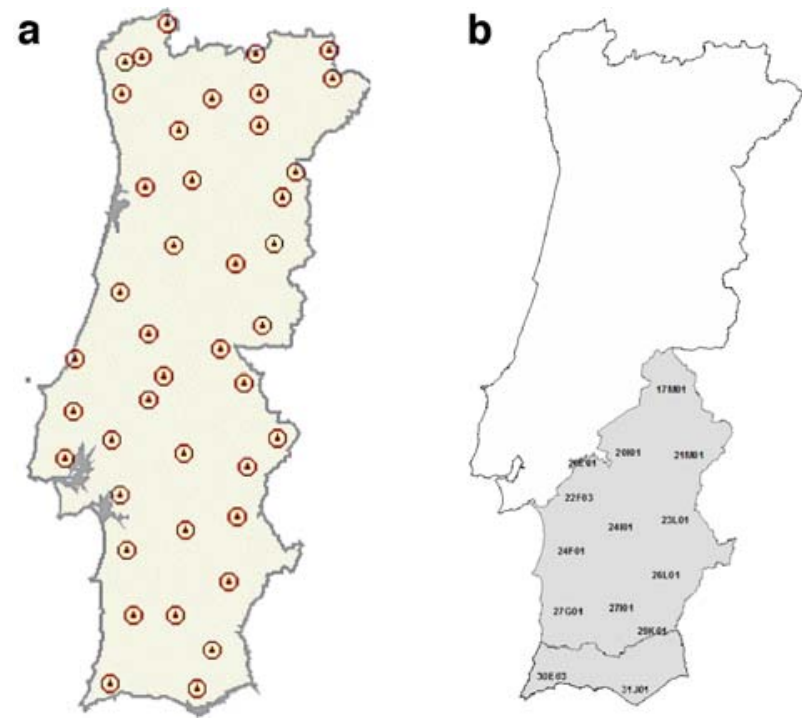

\section{Modeling}

\subsection{Markov Chains Modeling}

A order 1 Markov chain (Çinlar 1975) is a stochastic process $X$, such as at any time t, $X_{\mathrm{t}}+1$ is conditionally independent from $X_{0}, X_{1}, X_{2}, \ldots, X_{\mathrm{t}-1}$, given $X_{\mathrm{t}}$; the probability that $X_{\mathrm{t}+1}$ takes a particular value $j$ depends on the past only through its most recent value $X_{\mathrm{t}}$ :

$$
P\left\{X_{\mathrm{t}+1}=j \mid X_{0}, X_{1}, \ldots, X_{\mathrm{t}}\right\}=P\left\{X_{\mathrm{t}+1}=j \mid X_{\mathrm{t}}=i\right\} \forall i, j \in S, t \in T
$$

Table 1 Rainfall stations in Alentejo and Algarve: code, location, initial year of records and statistical characteristics of annual rainfall data

\begin{tabular}{lllllllll}
\hline Code & Name of stations & Initial date & $\begin{array}{l}\text { Longitude } \\
(\mathrm{W})\end{array}$ & $\begin{array}{l}\text { Latitude } \\
(\mathrm{N})\end{array}$ & $\begin{array}{l}\text { Altitude } \\
(\mathrm{m})\end{array}$ & $\begin{array}{l}\text { Median } \\
(\mathrm{mm})\end{array}$ & $\begin{array}{l}\text { Coef. of } \\
\text { variation }\end{array}$ & Skewness \\
\hline 17M01 & Castelo de Vide & $1931 / 32$ & $07^{\circ} 27^{\prime}$ & $39^{\circ} 25^{\prime}$ & 540 & 840.7 & 0.33 & 0.60 \\
20E01 & B. de Magos & $1937 / 38$ & $08^{\circ} 41^{\prime}$ & $39^{\circ} 00^{\prime}$ & 20 & 643.7 & 0.27 & 0.19 \\
20I01 & Pavia & $1931 / 32$ & $08^{\circ} 01^{\prime}$ & $38^{\circ} 54^{\prime}$ & 192 & 578.6 & 0.31 & 0.26 \\
21M01 & Vila Viçosa & $1931 / 32$ & $07^{\circ} 25^{\prime}$ & $38^{\circ} 47^{\prime}$ & 370 & 702.3 & 0.38 & 1.37 \\
22F03 & Moinhola & $1931 / 32$ & $08^{\circ} 37^{\prime}$ & $38^{\circ} 35^{\prime}$ & 39 & 665.6 & 0.28 & 0.59 \\
23L01 & Reguengos & $1931 / 32$ & $08^{\circ} 32^{\prime}$ & $38^{\circ} 25^{\prime}$ & 210 & 534.7 & 0.30 & 0.18 \\
24F01 & Grândola & $1931 / 32$ & $08^{\circ} 33^{\prime}$ & $38^{\circ} 11^{\prime}$ & 91 & 663.8 & 0.28 & 0.34 \\
24I01 & Viana do Alentejo & $1931 / 32$ & $08^{\circ} 00^{\prime}$ & $38^{\circ} 19^{\prime}$ & 230 & 669.9 & 0.28 & 0.19 \\
26L01 & Serpa & $1931 / 32$ & $07^{\circ} 36^{\prime}$ & $37^{\circ} 57^{\prime}$ & 190 & 499.3 & 0.34 & 0.43 \\
27G01 & Relíquias & $1931 / 32$ & $08^{\circ} 29^{\prime}$ & $37^{\circ} 42^{\prime}$ & 230 & 672.7 & 0.31 & 0.20 \\
27I01 & Castro Verde & $1931 / 32$ & $08^{\circ} 05^{\prime}$ & $37^{\circ} 42^{\prime}$ & 180 & 529.5 & 0.32 & 0.19 \\
29K01 & Martim Longo & $1940 / 41$ & $07^{\circ} 46^{\prime}$ & $37^{\circ} 26^{\prime}$ & 290 & 511.6 & 0.36 & 0.65 \\
30E03 & B. da Bravura & $1933 / 34$ & $08^{\circ} 42^{\prime}$ & $37^{\circ} 12^{\prime}$ & 75 & 663.9 & 0.32 & 0.50 \\
31J01 & S. Brás de Alportel & $1931 / 32$ & $07^{\circ} 54^{\prime}$ & $37^{\circ} 10^{\prime}$ & 325 & 813.6 & 0.33 & 0.50 \\
\hline
\end{tabular}


Equation 1 is often referred as the Markov property of a Markov chain. The independence of values that are separated by more than one time period is not required by the Markov property. Instead, it implies conditional independence of data values separated by more than one time period, which means that the statistical dependence among elements of the time series decreases as time lags increase (Wilks 1995). If the probability that $X$ will enter in state $j$ on the $k$ th step depends upon the sequence of states in steps $(k-m)$ through $(k-1)$, then the process is a $m$ th-order Markov chain $(m=1,2, \ldots)$.

The maximum likelihood parameter estimation of the first and second order Markov chains representing drought class transitions consists of computing the conditional relative frequencies for each drought class transition (Paulo et al. 2005; Paulo and Pereira 2007). The transition probability matrix of a first order Markov chain

$$
P=\left[p_{i j}\right]=P\left\{X_{\mathrm{t}+1}=j \mid X_{\mathrm{t}}=i\right\}
$$

is estimated from the sample, counting the number of times, $n_{i j}$, that the value $X_{\mathrm{t}}$ passes from the state $i$ to the state $j$ and given by:

$$
\hat{p}_{i j}=n_{i j} / \sum_{j} n_{i j}
$$

The sample dimension and the number of states influence the accuracy of estimates; the number of parameters of the model depends on the number of states. In Markov modeling 4 drought categories, or states, were considered: non-drought, near normal (or mild drought), moderate drought and severe or extreme drought. The respective thresholds are those proposed for the SPI (McKee et al. 1993; 1995) but grouping the severe and extremely severe classes (Table 2). The term near normal is used instead of mild drought because it reflects better the fact that this drought category corresponds to a dry condition identifying a possible initiation or end of a drought period (Paulo and Pereira 2007).

Markov chain modeling allows the estimation of the following items (see Appendix):

- The drought class probabilities, which represent the probabilities of occurrence of the various drought classes

- The expected residence time in each class of severity, which is the average time the process stays in a particular drought class before migrating to another class and represents the duration of that drought class;

- The expected first passage time that represents the average time period taken by the process to reach for the first time the drought class $j$ starting from some class $i$;

- The short-term drought class prediction, which is the most probable class one, 2 or 3 months ahead.

In the non-homogeneous formulation, 12 monthly transition probability matrices are considered because the probability of transition from state $i$ to state $j$ at time tepends on the month (Paulo et al. 2005; Paulo and Pereira 2007) as also referred in Appendix:

$$
P_{i j}^{(\mathrm{t}, \mathrm{t}+1)}=P\left(X_{\mathrm{t}+1}=j \mid X_{\mathrm{t}}=i\right), \forall i, j \in S
$$


Table 2 Upper bound of SPI drought categories and cumulated probabilities (McKee et al. 1993)

\begin{tabular}{lll}
\hline Drought category & SPI values & Cumulated probabilities \\
\hline Near normal (mild) & 0 & 0.50000 \\
Moderate drought & -1.00 & 0.15866 \\
Severe drought & -1.50 & 0.06681 \\
Extreme drought & -2.00 & 0.02275 \\
\hline
\end{tabular}

In the non-homogeneous formulation, the computation concerns the items that are dependent of the initial month since the transition probabilities between states are defined for each month. They are:

- The expected time in each class of severity,

- The expected first passage time, and

- The short-term drought class prediction relative to 1,2 or 3 months ahead.

The assumptions of the Markov property for the homogeneous formulation were verified through the log-likelihood ratio (LR) test (Anderson and Goodman 1957; Wilks 1995). Markov chains order 1 versus order 2 were tested. The LR statistic under the null hypothesis follows a chi-square distribution with $v=\left(s^{2}-s\right)(s-1)$ degrees of freedom, being $s$ the number of states. Zero observed and zero expected values do not account for the LR statistic. In those cases the degrees of freedom of the tests are diminished accordingly (Bishop et al. 1975; Bickenbach and Bode 2003).

The results of the log-likelihood ratio test considering $\alpha=0.05$ show that the Markov property is rejected in three stations (Table 3). The Markov property for the region holds with $p$-value $=0.577$. For the sites where the Markov property was rejected $(\alpha=0.05)$ the analysis that follows was not applied.

Table 3 Significance of Markov property

\begin{tabular}{|c|c|c|c|c|}
\hline \multirow[t]{2}{*}{ Code } & \multirow[t]{2}{*}{ Site } & \multicolumn{3}{|c|}{ Log-likelihood ratio statistics } \\
\hline & & $d f$ & LR & $p$-value \\
\hline $17 \mathrm{M} 01$ & Castelo de Vide & 16 & 20.35 & 0.2047 \\
\hline 20E01 & B. de Magos & 30 & 38.86 & 0.1288 \\
\hline $20 \mathrm{I} 01$ & Pavia & 21 & 22.38 & 0.3781 \\
\hline 21M01 & Vila Viçosa & 26 & 32.01 & 0.1927 \\
\hline $22 \mathrm{~F} 03$ & Moinhola & 21 & 33.74 & $0.0386^{\mathrm{a}}$ \\
\hline 23L01 & Reguengos & 25 & 38.68 & $0.0397^{\mathrm{a}}$ \\
\hline $24 \mathrm{~F} 01$ & Grândola & 21 & 29.08 & 0.1121 \\
\hline $24 \mathrm{I} 01$ & Viana do Alentejo & 26 & 25.99 & 0.4635 \\
\hline 26L01 & Serpa & 24 & 34.17 & 0.0816 \\
\hline 27G01 & Relíquias & 30 & 31.95 & 0.3699 \\
\hline $27 \mathrm{I} 01$ & Castro Verde & 21 & 29.12 & 0.1111 \\
\hline $29 \mathrm{~K} 01$ & Martim Longo & 18 & 26.74 & 0.0841 \\
\hline 30E03 & B. da Bravura & 26 & 22.02 & 0.6878 \\
\hline $31 \mathrm{~J} 01$ & S. Brás de Alportel & 21 & 34.74 & $0.0301^{\mathrm{a}}$ \\
\hline \multicolumn{2}{|c|}{ Alentejo region } & 28 & 25.93 & 0.5769 \\
\hline
\end{tabular}

\footnotetext{
${ }^{\mathrm{a}}$ Markov property rejected $(\alpha=0.05)$ 


\subsection{Estimation of Precipitation Deficits}

In previous studies using the Palmer index the amount of precipitation required to decrease drought severity has been computed over different time periods (Karl et al. 1987; Cancelliere et al. 1996). In this paper, the estimation of the precipitation deficits is based on the SPI thresholds for different drought categories and on the monthly gamma distribution functions used to compute the SPI in a 12-month time scale.

The question to be answered is: how much more cumulated precipitation would be needed in each drought month to decrease drought severity, i.e., to change from the present drought class to a less severe one, adopting the SPI drought severity classification based on that proposed by McKee et al. (1993). Assuming that the SPI is a random normal variable, $z$, the SPI drought class boundaries $z=0, z=-1, z=-1.5, z=-2$ are transformed into probabilities by

$$
\phi(z)=F(x)=P(X \leq x)
$$

where $\phi(z)$ is the normal distribution function (Table 2).

The gamma distribution function for each month is given by

$$
G(x)=\int_{0}^{x} g(\mathrm{t}) d \mathrm{t}=\frac{1}{\hat{\beta}^{\hat{\alpha}} \Gamma(\hat{\alpha})} \int_{0}^{x} \mathrm{t}^{\hat{\alpha}-1} \mathrm{e}^{-\frac{\mathrm{t}}{\hat{\beta}}} d \mathrm{t}
$$

where $\hat{\alpha}$ and $\hat{\beta}$ are the shape and scale parameter monthly estimates, and $x$ the cumulated precipitation value for the considered time scale. Then the cumulative probability of a given upper bound SPI value, $\phi(z)$, is made equal to the gamma distribution function

$$
\phi(z)=\frac{1}{\hat{\beta}^{\hat{\alpha}} \Gamma(\hat{\alpha})} \int_{0}^{x} \mathrm{t}^{\hat{\alpha}-1} \mathrm{e}^{-\frac{\mathrm{t}}{\hat{\beta}}} d \mathrm{t}
$$

and the equation

$$
x=G^{-1}(\phi(z))
$$

is solved in order to estimate the corresponding cumulated precipitation value $x$.

Moreover it is possible to estimate how much precipitation would be required in the next future month in order to decrease the drought severity. This precipitation amount is estimated by subtracting from the cumulated precipitation value obtained for a given drought class threshold for that month, the precipitation observed in the past 11 months if a 12-month time scale is considered.

\section{Stochastic Characteristics of Droughts Using Markov Chains}

For the sites where the Markov property was accepted, Markov modeling was applied to compute the probabilities of drought severity classes and the stochastic characteristics of droughts, which are referred below.

The probabilities of drought severity classes decrease with the degree of severity (Table 4). Relíquias and Castro Verde are exceptions in what concerns the moderate and severe/extreme drought categories. The probabilities for the non-drought class are similar for all the analyzed locations, ranging from 0.469 in Pavia to 0.524 in B. Bravura. 
Table 4 Drought class probabilities

\begin{tabular}{|c|c|c|c|c|}
\hline \multirow[t]{2}{*}{ Site } & \multicolumn{4}{|c|}{ Analytical steady state probabilities } \\
\hline & Non drought & Near normal & Moderate & Severe or extreme \\
\hline Castelo de Vide & 0.5075 & 0.3047 & 0.1306 & 0.0572 \\
\hline B. de Magos & 0.5213 & 0.3040 & 0.0880 & 0.0867 \\
\hline Pavia & 0.4693 & 0.3693 & 0.0931 & 0.0683 \\
\hline Vila Viçosa & 0.4846 & 0.3456 & 0.1031 & 0.0668 \\
\hline Grândola & 0.5013 & 0.3197 & 0.0943 & 0.0846 \\
\hline Viana do Alentejo & 0.4967 & 0.3265 & 0.1082 & 0.0685 \\
\hline Serpa & 0.5091 & 0.3230 & 0.0997 & 0.0681 \\
\hline Relíquias & 0.5132 & 0.3098 & 0.0798 & 0.0971 \\
\hline Castro Verde & 0.4959 & 0.3451 & 0.0556 & 0.1035 \\
\hline Martim Longo & 0.5149 & 0.3276 & 0.0831 & 0.0744 \\
\hline B. da Bravura & 0.5235 & 0.3040 & 0.0918 & 0.0807 \\
\hline Alentejo region & 0.4795 & 0.3653 & 0.0968 & 0.0585 \\
\hline
\end{tabular}

When considering more severe drought classes, the relative differences between sites are higher. As an example, the probability of the severe or extreme drought class in Castelo de Vide is 0.057 while in Castro Verde it is twice 0.104. If the near normal class would be considered among the drought classes their respective cumulated probability of drought occurrence exceeds 0.50 in some locations as well as for the region. For this reason, the term mild drought proposed by McKee et al. (1993) was replaced by near normal to identify a dry but less severe condition.

The residence time represents the average duration of each drought class and therefore its persistence. The non-drought class is the more persistent, with a duration ranging from 8.9 months (Castro Verde) to 16.3 months (Castelo de Vide) in all locations and in the region (Table 5).

Table 5 Expected residence time in each class of severity (months)

\begin{tabular}{|c|c|c|c|c|}
\hline \multirow[t]{2}{*}{ Site } & \multicolumn{4}{|c|}{ Residence time (months) in each class of severity } \\
\hline & Non drought & Near normal & Moderate & Severe/extreme \\
\hline Castelo de Vide & 16.3 & 4.3 & 2.3 & 3.5 \\
\hline B. de Magos & 9.7 & 4.0 & 2.1 & 3.7 \\
\hline Pavia & 10.4 & 5.0 & 2.1 & 3.6 \\
\hline Vila Viçosa & 13.5 & 5.5 & 2.4 & 4.0 \\
\hline Grândola & 10.4 & 4.1 & 2.2 & 4.9 \\
\hline Viana doAlentejo & 10.8 & 3.9 & 1.8 & 3.2 \\
\hline Serpa & 11.5 & 4.5 & 2.3 & 3.4 \\
\hline Relíquias & 10.1 & 4.0 & 1.7 & 4.2 \\
\hline Castro Verde & 8.9 & 4.2 & 1.4 & 5.8 \\
\hline Martim Longo & 10.4 & 4.5 & 2.1 & 5.2 \\
\hline B. da Bravura & 11.4 & 4.2 & 2.0 & 3.6 \\
\hline Alentejo region & 11.0 & 5.5 & 2.5 & 4.2 \\
\hline
\end{tabular}


Table 6 Expected residence time (months) of drought classes in October, January and April

\begin{tabular}{|c|c|c|c|c|c|}
\hline \multirow[t]{2}{*}{ Site } & \multirow[t]{2}{*}{ Initial month } & \multicolumn{4}{|l|}{ Initial state } \\
\hline & & Non-drought & Near normal & Moderate & Severe/extreme \\
\hline \multirow[t]{3}{*}{ Castelo de Vide } & Oct & 13.6 & 3.0 & 1.7 & 2.0 \\
\hline & Jan & 14.1 & 3.1 & 2.1 & 2.0 \\
\hline & Apr & 14.1 & 3.3 & 1.8 & 1.6 \\
\hline \multirow[t]{3}{*}{ Pavia } & Oct & 8.7 & 3.3 & 2.0 & 2.2 \\
\hline & Jan & 8.8 & 3.2 & 2.1 & 2.1 \\
\hline & Apr & 9.1 & 4.0 & 1.8 & 2.7 \\
\hline \multirow[t]{3}{*}{ Vila Viçosa } & Oct & 10.5 & 3.8 & 2.1 & 1.9 \\
\hline & Jan & 11.5 & 3.8 & 1.5 & 2.4 \\
\hline & Apr & 12.5 & 4.0 & 2.5 & 2.9 \\
\hline \multirow[t]{3}{*}{ Castro Verde } & Oct & 7.6 & 2.6 & 1.0 & 2.4 \\
\hline & Jan & 7.4 & 2.5 & 1.3 & 3.0 \\
\hline & Apr & 8.2 & 2.9 & 1.2 & 3.0 \\
\hline \multirow[t]{3}{*}{ Alentejo region } & Oct & 9.8 & 2.5 & 1.8 & 1.4 \\
\hline & Jan & 9.8 & 4.1 & 1.4 & 1.5 \\
\hline & Apr & 10.4 & 4.5 & 1.3 & 1.9 \\
\hline
\end{tabular}

It can be observed that the more severe drought class has a higher duration than the moderate drought in all sites and in the region. Differences between sites are especially relevant for the more severe drought class whose estimated values range from 5.8 (Castro Verde) to 3.2 months (Viana do Alentejo). However, the residence times vary along the year depending upon the initial state at the considered month, as shown for some sites in Table 6. Higher values refer to April because the rainy season ends by then (see Fig. 1) and no significant rains are expected until October that could lead to a quick transition from drought class.

The expected time to reach the non-drought class increases with the degree of severity of the initial drought class (Table 7). The expected time for all the possible transitions between drought classes in Alentejo region is presented in Fig. 3. Generally the expected time for the transition between drought classes is higher when the classes are more apart. Results show that drought initiation and establishment is a slower process than drought dissipation.

Table 7 Expected time (months) to reach the non-drought class from any drought class

\begin{tabular}{llll}
\hline Site & \multicolumn{2}{l}{$\begin{array}{l}\text { Expected time (months) to reach the non-drought class when the initial } \\
\text { drought class is: }\end{array}$} \\
\cline { 2 - 4 } & Near normal & Moderate & Severe or extreme \\
\hline Castelo de Vide & 8.8 & 13.3 & 14.4 \\
B. de Magos & 8.7 & 13.6 & 15.4 \\
Pavia & 11.8 & 16.6 & 19.3 \\
Vila Viçosa & 14.2 & 19.2 & 22.4 \\
Grândola & 10.3 & 13.6 & 17.5 \\
Viana do Alentejo & 10.8 & 14.1 & 16.9 \\
Serpa & 11.1 & 14.9 & 16.6 \\
Relíquias & 9.5 & 14.1 & 17.0 \\
Castro Verde & 9.0 & 13.7 & 17.8 \\
Martim Longo & 10.1 & 14.1 & 18.4 \\
B. da Bravura & 10.3 & 15.4 & \\
\hline
\end{tabular}


For example the expected time for the transition between non-drought and moderate drought is 37 months while for the moderate to non-drought transition is 16 months. The transition from non-drought to severe/extreme drought will take in average 61 months while the time expected for the inverse transition is 18 months.

\section{Short-Term Drought Class Predictions}

Markov transition probability matrices show a strong diagonal tendency as already observed for other locations (Paulo et al. 2005). This trend reflects the fact that "droughts are self-perpetuating" (NSSTC 2003). The predictions in Table 8 reflect the persistence of recent weather categories: when the actual state is "non-drought" or "near normal" the more probable state 1, 2 or 3 months ahead is the present state, i.e. no changes of state are predictable. However, when the initial state is moderate drought the predicted states 2 or 3 months ahead are different from those initial. Therefore, despite limitations in the Markov chains modeling, these results open a window on the respective prediction capabilities.

Results from non-homogeneous Markovian modeling reflect the seasonality of precipitation and how this affects the potential retreat of drought. For example, it is evidenced (Table 9 and Fig. 4) that it is more probable to get out of a drought by October, when the rainy season starts, then by January, in the mid of the rainy season, when the occurrence of a drought clear indicates that a persistent atmospheric anomaly is installed, or by April, which is close to the start of the non-rainy season. Despite droughts are hazards, these results show that the evolution of the drought events is well related with the climate patterns.

\section{Prediction of Drought Class Transitions: Testing for a Recent Drought Event}

Extreme or severe droughts were observed in all sites by October 2005 (Table 10). By November the severe/extreme drought class is still observed in eight sites while a decrease in drought severity from the severe/extreme class to the moderate one was attained in three locations. A slow recover was later observed and by the end of March eight sites were classified as near normal with only three locations (Castelo de Vide, Pavia e Viana do Alentejo) still under moderate drought.

Fig. 3 Expected time (months) to reach the non-drought (white columns), near normal (mild drought; light gray columns), moderate drought (dark gray columns) and severe or extreme drought (black columns), in Alentejo region

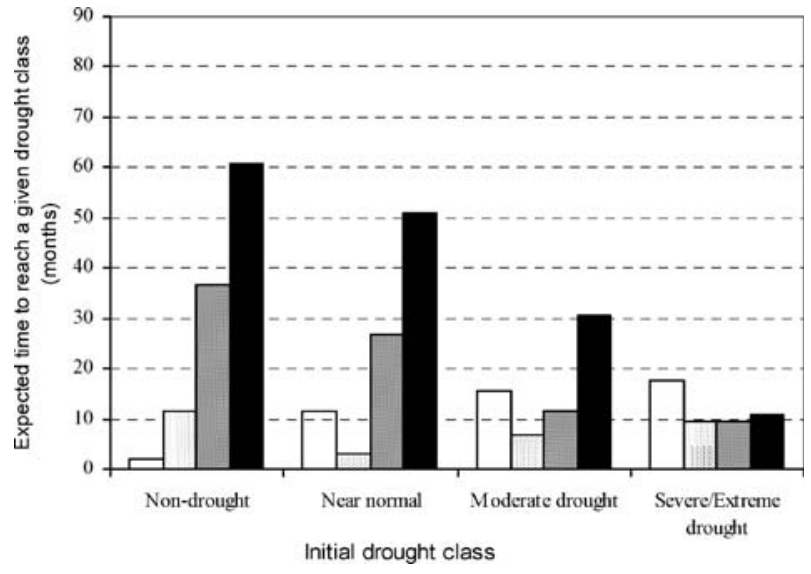

Initial drought class 
Table 8 More probable state 1,2 and 3 months ahead given an initial state at selected locations and the region

\begin{tabular}{|c|c|c|c|c|c|c|}
\hline \multirow[t]{2}{*}{ Initial State } & \multicolumn{2}{|c|}{1 month ahead } & \multicolumn{2}{|c|}{2 months ahead } & \multicolumn{2}{|c|}{3 months ahead } \\
\hline & State & Probability & State & Probability & State & Probability \\
\hline \multicolumn{7}{|l|}{ Pavia } \\
\hline $\mathrm{N}$ & $\mathrm{N}$ & 0.904 & $\mathrm{~N}$ & 0.829 & $\mathrm{~N}$ & 0.769 \\
\hline 1 & 1 & 0.801 & 1 & 0.674 & 1 & 0.588 \\
\hline 2 & 2 & 0.527 & 1 & 0.370 & 1 & 0.406 \\
\hline 3 & 3 & 0.724 & 3 & 0.567 & 3 & 0.465 \\
\hline \multicolumn{7}{|l|}{ Castro Verde } \\
\hline $\mathrm{N}$ & $\mathrm{N}$ & 0.887 & $\mathrm{~N}$ & 0.805 & $\mathrm{~N}$ & 0.744 \\
\hline 1 & 1 & 0.763 & 1 & 0.628 & 1 & 0.541 \\
\hline 2 & 1 & 0.419 & 1 & 0.455 & 1 & 0.431 \\
\hline 3 & 3 & 0.827 & 3 & 0.721 & 3 & 0.640 \\
\hline \multicolumn{7}{|c|}{ Alentejo region } \\
\hline $\mathrm{N}$ & $\mathrm{N}$ & 0.915 & $\mathrm{~N}$ & 0.846 & $\mathrm{~N}$ & 0.790 \\
\hline 1 & 1 & 0.818 & 1 & 0.696 & 1 & 0.611 \\
\hline 2 & 2 & 0.605 & 1 & 0.407 & 1 & 0.412 \\
\hline 3 & 3 & 0.762 & 3 & 0.603 & 3 & 0.492 \\
\hline
\end{tabular}

N Non-drought; 1 near normal; 2 moderate drought; 3 severe or extreme drought

Following the approaches outlined in section 3, and already early tested (Paulo et al. 2005; Paulo and Pereira 2007), the predictions of drought class transitions 1, 2 and 3 months ahead, are presented in Table 11 relative to the months November 2005 to May 2006. Results are not excellent but useful: a trend for drought evolution is predicted with some accuracy (comparing observed data in Table 10 with predictions in Table 11). Predictions 3-month ahead are only indicative and should be read together with predictions for the antecedent months, not by themselves alone. Predictions 1-month ahead are enough accurate since they give a relatively good trend. However, when exceptional rains occur, the trend for drought evolution is accelerated, sometimes modified; for periods when drought is increasing severity results are more easily predicted.

Table 9 Expected time (months) to reach the non-drought class from any drought class given the initial month for selected sites

\begin{tabular}{|c|c|c|c|c|c|}
\hline \multirow[t]{2}{*}{ Initial class } & \multicolumn{5}{|l|}{ Site } \\
\hline & Pavia & Viana do Alentejo & Relíquias & Martim Longo & Grândola \\
\hline \multicolumn{6}{|c|}{ Initial month: October } \\
\hline Near normal & 10.5 & 10.5 & 8.3 & 9.7 & 10.3 \\
\hline Moderate & 14.7 & 12.9 & 9.7 & 11.4 & 11.1 \\
\hline Severe/Extreme & 17.3 & 13.2 & 15.4 & 15.9 & 13.2 \\
\hline \multicolumn{6}{|c|}{ Initial month: January } \\
\hline Near normal & 10.6 & 10.6 & 9.3 & 9.1 & 8.9 \\
\hline Moderate & 18.1 & 16.9 & 14.2 & 16.3 & 16.9 \\
\hline Severe/Extreme & 20.4 & 17.0 & 18.4 & 19.4 & 16.9 \\
\hline \multicolumn{6}{|l|}{ Initial month: April } \\
\hline Near normal & 12.8 & 11.3 & 10.4 & 11.2 & 10.5 \\
\hline Moderate & 16.2 & 15.3 & 15.0 & 14.1 & 14.5 \\
\hline Severe/Extreme & 20.9 & 17.6 & 16.9 & 20.3 & 17.9 \\
\hline
\end{tabular}


Fig. 4 Expected time (months) for the transition from near normal (open squares), moderate (closed triangles), and severe or extreme drought (crosses) to non-drought, given the initial state, Alentejo



The ending of drought during the winter season when rains are expected, such as by December, has not been predicted in any of the 11 locations where Markov models have been applied. Instead, the sharp decrease of drought severity by December using 2 and 3-month predictions was wrongly predicted but that trend was later confirmed. For February, yet during the rainy season, predictions for all locations 1-month ahead are very good; however, those 2- and 3month ahead are less good but in agreement with the detected trend for drought dissipation.

The prediction of drought dissipation is quite well performed for April and May, both 2 and, mainly, 1-month ahead. However, results 3-month ahead are relatively poor since rains that accelerate the dissipation occurred after the release of the prediction.

In this study, the predicted drought class 1, 2 or 3 months ahead is defined from the highest probability among all drought class transitions from the considered initial state. The analysis of results show that, to improve the information, it is advisable to modify the prediction approach by selecting a couple of predictable drought classes instead of one only when the probabilities of transitions for both classes are not enough different. However, it is necessary to establish a threshold on the difference between probabilities to adequately formulating the prediction. In fact, in that way, any possible trend is more easily detected.

A further improvement already tested is to combine predictions performed using the described Markov chains modeling with those obtained from Loglinear modeling (Paulo et al. 2005). In addition, computing the precipitation deficits and building precipitation scenarios for the forthcoming months also help to interpret results and detecting trends. This approach is described below.

Table 10 Observed drought severity classes in several sites of Alentejo and Algarve for the period October 2005-May 2006

\begin{tabular}{lllllllll}
\hline Site & Oct-05 & Nov-05 & Dec-05 & Jan-06 & Feb-06 & Mar-06 & Apr-06 & May-06 \\
& Observed drought classes & & & & & \\
\hline Castelo de Vide & Sev/Extr & Sev/Extr & Sev/Extr & Sev/Extr & Sev/Extr & Moderate & Near norm & Moderate \\
B. de Magos & Sev/Extr & Sev/Extr & Sev/Extr & Moderate & Near norm & Near norm & Near norm Near norm \\
Pavia & Sev/Extr & Sev/Extr & Sev/Extr & Sev/Extr & Sev/Extr & Moderate & Moderate & Moderate \\
Vila Viçosa & Sev/Extr & Sev/Extr & Sev/Extr & Sev/Extr & Moderate & Near norm & Near norm Near norm \\
Grandola & Sev/Extr & Sev/Extr & Sev/Extr & Sev/Extr & Moderate & Near norm & Near norm & Near norm \\
Viana do Alentejo & Sev/Extr & Sev/Extr & Sev/Extr & Sev/Extr & Sev/Extr & Moderate & Near norm Moderate \\
Serpa & Sev/Extr & Moderate & Moderate & Near norm & Near norm & Near norm & Near norm Near norm \\
Relíquias & Sev/Extr & Sev/Extr & Moderate & Moderate & Near norm & Near norm & Near norm Near norm \\
Castro Verde & Sev/Extr & Sev/Extr & Sev/Extr & Moderate & Near norm & Near norm & Near norm Near norm \\
Martim Longo & Sev/Extr & Moderate & Near norm & Near norm & Near norm & Near norm & Normal & Near norm \\
B. Bravura & Sev/Extr & Moderate & Moderate & Moderate & Near norm & Near norm & Near norm Near norm \\
\hline
\end{tabular}


Table 11 Drought severity classes predicted 1,2 and 3 months-ahead for the study sites in Alentejo and Algarve for the months November 2005 to May 2006

\begin{tabular}{|c|c|c|c|c|c|c|c|}
\hline Site & Nov-05 & Dec-05 & Jan-06 & Feb-06 & Mar-06 & Apr-06 & May-06 \\
\hline \multicolumn{8}{|c|}{ Monthly drought classes predicted 1-month ahead } \\
\hline Castelo de Vide & $\mathrm{Sev} /$ Extr & Moderate & Sev/Extr & Sev/Extr & Sev/Extr & Sev/Extr & $\mathrm{Ne}$ \\
\hline B. de Magos & Sev/Extr & Moderate & Sev/Extr & Moderate & Near norm & Near norm & Near norm \\
\hline Pavia & $\mathrm{Sev} /$ Extr & Moderate & Sev/Extr & Sev/Extr & Sev/Extr & Sev/Extr & Near norm \\
\hline Vila Viçosa & Sev/Extr & Near norm & Sev/Extr & Sev/Extr & Moderate & Near norm & norm \\
\hline Grandola & Sev/Extr & Sev/Extr & Sev/Extr & Sev/Extr & Moderate & Near norm & Near norm \\
\hline Viana do Alentejo & Sev/Extr & Sev/Extr & Sev/Extr & Moderate & Sev/Extr & Moderate & Near norm \\
\hline Serpa & Moderate & Sev/Extr & Moderate & Near norm & Near norm & Near norm & Near norm \\
\hline Relíquias & Sev/Extr & Sev/Extr & Near norm & Near norm & Near norm & Near norm & Near norm \\
\hline Castro Verde & $\mathrm{Sev} / \mathrm{Extr}$ & Moderate & Sev/Extr & Near norm & Near norm & Near norm & Near norm \\
\hline Martim Longo & Sev/Extr & Moderate & Near norm & Near norm & Near norm & Near norm & Normal \\
\hline B.Bravura & Sev/Extr & Moderate & Moderate & Near norm & Near norm & Near norm & Near norm \\
\hline
\end{tabular}

Monthly drought classes predicted 2-months ahead

$\begin{array}{llllllll}\text { Castelo de Vide } & \text { Sev/Extr } & \text { Moderate } & \text { Moderate } & \text { Sev/Extr } & \text { Sev/Extr } & \text { Near norm } & \text { Sev/Extr } \\ \text { B. de Magos } & \text { Sev/Extr } & \text { Moderate } & \text { Near norm } & \text { Near norm } & \text { Near norm } & \text { Near norm Near norm } \\ \text { Pavia } & \text { Sev/Extr } & \text { Moderate } & \text { Near norm } & \text { Sev/Extr } & \text { Sev/Extr } & \text { Sev/Extr } & \text { Near norm } \\ \text { Vila Viçosa } & \text { Moderate } & \text { Near norm } & \text { Moderate } & \text { Sev/Extr } & \text { Sev/Extr } & \text { Near norm Near norm } \\ \text { Grandola } & \text { Sev/Extr } & \text { Near norm } & \text { Sev/Extr } & \text { Sev/Extr } & \text { Sev/Extr } & \text { Moderate } & \text { Near norm } \\ \text { Viana do Alentejo } & \text { Moderate } & \text { Near norm } & \text { Near norm } & \text { Moderate } & \text { Near norm } & \text { Moderate } & \text { Near norm } \\ \text { Serpa } & \text { Moderate } & \text { Sev/Extr } & \text { Sev/Extr } & \text { Near norm } & \text { Near norm } & \text { Near norm Near norm } \\ \text { Relíquias } & \text { Sev/Extr } & \text { Sev/Extr } & \text { Sev/Extr } & \text { Near norm } & \text { Near norm } & \text { Near norm Near norm } \\ \text { Castro Verde } & \text { Sev/Extr } & \text { Moderate } & \text { Near norm } & \text { Sev/Extr } & \text { Near norm } & \text { Near norm Near norm } \\ \text { Martim Longo } & \text { Sev/Extr } & \text { Sev/Extr } & \text { Moderate } & \text { Near norm } & \text { Near norm } & \text { Near norm Near norm } \\ \text { B.Bravura } & \text { Moderate } & \text { Moderate } & \text { Moderate } & \text { Sev/Extr } & \text { Near norm } & \text { Near norm Near norm }\end{array}$

Monthly drought classes predicted 3-months ahead

\begin{tabular}{llllllll} 
Castelo de Vide & Sev/Extr & Moderate & Moderate & Near norm & Sev/Extr & Near norm & Near norm \\
B. de Magos & Sev/Extr & Moderate & Near norm & Sev/Extr & Sev/Extr & Sev/Extr & Near norm \\
Pavia & Moderate & Moderate & Near norm & Near norm & Sev/Extr & Sev/Extr & Sev/Extr \\
Vila Viçosa & Moderate & Near norm & Moderate & Near norm & Sev/Extr & Sev/Extr & Near norm \\
Grandola & Moderate & Near norm & Sev/Extr & Near norm & Sev/Extr & Sev/Extr & Near norm \\
Viana do Alentejo & Moderate & Near norm & Near norm & Moderate & Near norm & Near norm & Sev/Extr \\
Serpa & Moderate & Sev/Extr & Near norm & Sev/Extr & Near norm & Near norm & Near norm \\
Relíquias & Sev/Extr & Near norm & Sev/Extr & Sev/Extr & Near norm & Moderate & Near norm \\
Castro Verde & Sev/Extr & Moderate & Near norm & Near norm & Sev/Extr & Near norm Near norm \\
Martim Longo & Sev/Extr & Sev/Extr & Moderate & Sev/Extr & Near norm & Near norm Near norm \\
B.Bravura & Near norm & Near norm & Moderate & Near norm & Sev/Extr & Near norm Near norm \\
\hline
\end{tabular}

\section{Using Precipitation Deficits in Addition to the Markov Modeling Predictions}

The 2004-2006 drought in the South of Portugal was characterized using the SPI in a 12-month time scale. This drought was only officially recognized by April 2005, at the end of the rainy season, because information from drought indices could be then confirmed by indices relative to hydrological variables such as reservoir storage. However, using the SPI the drought initiation 
could be detected much earlier (Table 12). If some predictive tools would then be used it would have been more easy to recognize that drought was installed much before that date. Observing Table 12, it can be seen that droughts that initiated earlier have generally a larger number of months in the near normal class than those initiating later. This indicates that, for this drought event, those locations had a lead-time longer than the latter. In other words, the commonly called mild class is effectively a near normal class which could be used to advise on the possible installation of a drought. The lead-time may then be defined as the number of months within a drought event before SPI $\leq-1$ is reached. Data also show that often after the confirmation of a drought (SPI $\leq-1)$ no near normal months are included in the drought period until dissipation starts, in agreement with the analysis relative to drought class transitions in the previous section; the remaining months concern then moderate or more severe drought classes.

In Fig. 5, for selected sites, are presented the time evolution of the SPI 12-month and the amount of precipitation needed each month to reach the severe, moderate, near normal and non-drought classes from the actual state in every month from October 2000 to December 2005. Horizontal lines are the SPI thresholds below which the site enters in a more severe drought class; the upper line is the threshold below which the site starts to be in the near normal class when it was before in the non-drought class. The vertical stacked columns correspond to the amount of precipitation required to move the drought condition to a less severe class considering the precipitation observed by that month. Castelo de Vide is presented as an example. The stacked column in December 2005 has the following limits: $21 \mathrm{~mm}$, which correspond to the extra amount of precipitation needed to reach the severe drought, $107 \mathrm{~mm}$ the extra precipitation needed for the transition to moderate drought. The transition to the near normal class would require an extra amount of $204 \mathrm{~mm}$ and drought would end by December 2005 if more $432 \mathrm{~mm}$ have been observed in the last 12 months. Relationships between drought classes and precipitation are described in section 3.2.

Results for Viana do Alentejo show a quite large lead-time, with precipitation deficits starting by January 2002 but with the moderate drought installed only 2 years later. For Grandola a short moderate drought is identified during 2002 but it dissipated later; and the 2004-2006 drought initiates by December 2003. The behavior for Bravura is similar to Grandola but the 2003 drought occurred later and was milder. All four sites were in an uninterrupted drought period by January 2004, with aggravated severity by October. Dissipation started about 1 year later, but the decrease of severity was slow except for

Table 12 Estimated initiation of the 2004-2006 drought in Alentejo and Algarve and number of months in each drought severity class since that date until dissipation has initiated by November 2005

\begin{tabular}{|c|c|c|c|c|c|}
\hline \multirow[t]{2}{*}{ Location } & \multirow[t]{2}{*}{ Initiation month } & \multicolumn{4}{|c|}{ Number of months in drought class } \\
\hline & & Extreme & Severe & Moderate & Near normal \\
\hline Castelo de Vide & Sep-03 & 11 & 1 & 11 & 4 \\
\hline B. de Magos & Feb-04 & 9 & 3 & 1 & 9 \\
\hline Pavia & Sep-03 & 12 & 1 & 10 & 4 \\
\hline Vila Viçosa & Dec-03 & 1 & 10 & 2 & 11 \\
\hline Grândola & Dec-03 & 12 & 1 & 4 & 7 \\
\hline Viana do Alentejo & Jan-02 & 10 & 2 & 14 & 21 \\
\hline Serpa & Jan-04 & 9 & 3 & 1 & 10 \\
\hline Relíquias & Sep-03 & 11 & 2 & 1 & 13 \\
\hline Castro Verde & Apr-04 & 11 & 1 & 1 & 7 \\
\hline Martim Longo & Oct-04 & 5 & 4 & 4 & 1 \\
\hline B. da Bravura & Jan-04 & 10 & 2 & 2 & 9 \\
\hline
\end{tabular}





Fig. 5 Time evolution of the SPI 12-month and amount of precipitation needed to reach the severe (black columns), moderate (dark gray columns), near normal (light gray columns) and non-drought (white columns) classes from the actual state in every month from July 2001 to June 2006 in selected sites of Alentejo and Algarve. Horizontal lines are the SPI thresholds below which the site enters in a more severe drought class

Bravura. Rainfall starts to increase by September-October 2005; however, by December drought still is installed. Although significant precipitation occurred in October, November and December it has not been enough to re-establish non-drought conditions. Using this approach in combination with the predictions with the Markov modeling is helpful for information of users because common people visualize better a precipitation deficit than a drought index. Trends are then easily understood.

The monthly mean, the monthly median, and the amount of precipitation needed in selected months to reach the moderate (SPI $=-1.5)$, the mild $(\mathrm{SPI}=-1)$ and the non-drought class $(\mathrm{SPI}=0)$ given the observed precipitation in the previous 11 months, are presented in Table 13. Observing data for December 2005, it can be observed that the amount of precipitation needed to decrease to the moderate severity class is much above the precipitation observed in that month for most of sites. Combining this information with that provided from prediction modeling, it is adequate to predict that the trend for those locations is for maintaining the drought severity. Contrarily, where the observed rainfall is above that required for changing into the moderate class, the supported trend would be to decrease severity. An exception is Martim Longo where precipitation in October was much above the mean. For January conditions change little relative to December; thus, except for the last four sites in Table 13, observed conditions would favor maintenance of drought classes or its aggravation. The main information would come then from the probabilities of drought class transitions, as analyzed in the precedent Sections. For April, results show a situation that may be interpreted as for drought dissipation, so confirming the results from Markov modeling.

Results of this type are easy to be understood by common users. They show how far a given site is from changing to a less severe or the non-drought class and, by considering the mean and median precipitation of the month, how feasible it is that such precipitation will 
Table 13 Precipitation scenarios $(\mathrm{mm})$ for selected months

\begin{tabular}{|c|c|c|c|c|c|c|c|}
\hline & \multirow[t]{2}{*}{ Location } & \multicolumn{2}{|c|}{$\begin{array}{l}\text { Precipitation } \\
(1932-2005)\end{array}$} & \multicolumn{3}{|c|}{$\begin{array}{l}\text { Amount of precipitation } \\
(\mathrm{mm}) \text { needed to reach: }\end{array}$} & \multirow[t]{2}{*}{$\begin{array}{l}\text { Observed rainfall } \\
\text { in that month }\end{array}$} \\
\hline & & Mean & Median & $\begin{array}{l}\text { Non } \\
\text { drought }\end{array}$ & $\begin{array}{l}\text { Near } \\
\text { normal }\end{array}$ & $\begin{array}{l}\text { Moderate } \\
\text { drought }\end{array}$ & \\
\hline \multirow[t]{11}{*}{ Dec. 2005} & Castelo de Vide & 124 & 90 & 500 & 271 & 174 & 67.5 \\
\hline & B. de Magos & 90 & 77 & 287 & 136 & 70 & 40.5 \\
\hline & Pavia & 80 & 67 & 343 & 194 & 131 & 51.9 \\
\hline & Vila Viçosa & 107 & 83 & 416 & 210 & 124 & 57.9 \\
\hline & Grandola & 101 & 82 & 349 & 192 & 124 & 71.3 \\
\hline & Viana do Alentejo & 99 & 78 & 418 & 255 & 184 & 76.5 \\
\hline & Serpa & 69 & 56 & 227 & 84 & 23 & 44.8 \\
\hline & Relíquias & 99 & 70 & 323 & 146 & 71 & 72.1 \\
\hline & Castro Verde & 72 & 49 & 250 & 117 & 60 & 50.3 \\
\hline & Martim Longo & 68 & 57 & 189 & 37 & 0 & 52.7 \\
\hline & B. da Bravura & 98 & 85 & 337 & 152 & 75 & 86.4 \\
\hline \multirow[t]{11}{*}{ Jan. 2006} & Castelo de Vide & 124 & 90 & 433 & 203 & 105 & 27.1 \\
\hline & B. de Magos & 90 & 77 & 249 & 102 & 38 & 43.3 \\
\hline & Pavia & 80 & 67 & 293 & 147 & 84 & 32.4 \\
\hline & Vila Viçosa & 107 & 83 & 355 & 142 & 53 & 25.9 \\
\hline & Grandola & 101 & 82 & 282 & 128 & 60 & 38.3 \\
\hline & Viana do Alentejo & 99 & 78 & 343 & 177 & 106 & 26.1 \\
\hline & Serpa & 69 & 56 & 180 & 34 & 0 & 48.2 \\
\hline & Relíquias & 99 & 70 & 251 & 70 & 0 & 64.1 \\
\hline & Castro Verde & 72 & 49 & 202 & 71 & 15 & 60.9 \\
\hline & Martim Longo & 68 & 57 & 138 & 0 & 0 & 61.9 \\
\hline & B. da Bravura & 98 & 85 & 256 & 75 & 0 & 64.1 \\
\hline \multirow[t]{11}{*}{ Apr. 2006} & Castelo de Vide & 72.8 & 65.1 & 312 & 68 & 0 & 70.1 \\
\hline & B. de Magos & 56.2 & 54.8 & 139 & 0 & 0 & 54.2 \\
\hline & Pavia & 52.5 & 43.7 & 205 & 49 & 0 & 30.6 \\
\hline & Vila Viçosa & 58.3 & 48.9 & 207 & 0 & 0 & 40 \\
\hline & Grandola & 57.3 & 45.6 & 0 & 0 & 0 & 51.7 \\
\hline & Viana do Alentejo & 61.9 & 56.1 & 205 & 24 & 0 & 52.7 \\
\hline & Serpa & 53.3 & 46.1 & 63 & 0 & 0 & 22.7 \\
\hline & Relíquias & 59.7 & 53.6 & 111 & 0 & 0 & 31 \\
\hline & Castro Verde & 50.8 & 43.9 & 64 & 0 & 0 & 25.3 \\
\hline & Martim Longo & 43.2 & 36.4 & 34 & 0 & 0 & 36.4 \\
\hline & B. da Bravura & 55.4 & 50.8 & 73 & 0 & 0 & 43.8 \\
\hline
\end{tabular}

occur. These results combine well with predictions, both to help interpreting detected trends and to release information to users.

\section{Conclusions}

Markov chains have been applied in several locations of Southern Portugal and possible transitions between drought severity classes defined with the SPI 12-month have been evaluated. Markov chains clearly help to understand the stochastic characteristics of droughts. The duration of a given drought class severity is approached by the residence time in that class. The expected time for the transition between drought severity classes may 
be used as an indicator of drought evolution. The expected residence time in the near normal class before moderate drought is reached may be considered as the lead-time for that site, which justifies adopting the designation near normal for that drought class. The expected time for the transition between near normal and moderate drought classes can be interpreted as the average time needed to the establishment of a drought since usually, in a sequence of drought months, transitions from near normal to more severe drought classes are much less frequent. The transition time from moderate drought to the non-drought class may be interpreted as the time needed for drought dissipation and re-establishment of normal conditions.

Despite some limitations in drought prediction 2 and 3 months ahead the probabilistic evaluation of all possible transitions between an initial state in a given month and a final state 2 or 3 months may be obtained using a Markov modeling approach. For the test period focusing on the later months of the 2004-2006 drought, acceptable results were obtained for predicting short term drought class transitions. Along with this Markov modeling approach, Log linear modeling may be used as a complementary stochastic tool since the comparison between two possible transitions is made by statistical inference, namely confidence intervals, and not simply by choosing as future state the one which is more probable.

The computation of precipitation deficits helps a better understanding of how much precipitation would be needed to reach a less severe drought class in a given month. The temptation of using indicators that are based on hydrological variables without any probabilistic base just because they provide a more clear connection with the physical world can be overcome with this translation of the SPI values into precipitation deficits. In addition, different precipitations scenarios for future months can show how the SPI index would change with precipitation. Using these tools together with Markov modeling improves interpretation of possible trends in drought evolution and provides information easier to understand by common users. Further developments are foreseen by combining these stochastic approaches with the analysis of weather regimes.

Acknowledgements This research was funded by the INTERREG project SEDEMED I and II. The support of the Agricultural Engineering Research Center is also acknowledged.

\section{Appendix}

Markov chains modeling applied to drought class transitions

In the long-term, the drought class probabilities $\pi_{j}$, also referred as steady-state probabilities, are independent of the initial state of the Markov chain (Eq. 1). These probabilities are the unique solution of the system of linear equations:

$$
\left\{\begin{array}{l}
\pi_{j}=\sum_{k \in S} \pi_{k} P_{k j}, j \in S \\
1=\sum_{j \in S} \pi_{j}
\end{array}\right.
$$

where $\pi_{j}$ is the long-term probability of drought class $j$, i.e.,

$$
\pi_{j}=\lim _{t \rightarrow \infty \forall i} P\left(X_{t}=j \mid X_{0}=i\right), i \wedge j \in S
$$

where other variables are defined for Eqs. 1 and 2. 
The probability of an uninterrupted stay, during $m$ months, in a particular class $i$ corresponds to the product of the probabilities of the successive transitions between $X_{0}$ and $X_{m}$ and is given by:

$$
\begin{aligned}
& P\left(X_{1}=i \mid X_{0}=i\right) P\left(X_{2}=i \mid X_{1}=i\right) \cdots P\left(X_{m-2}=i \mid X_{m-1}=i\right) P\left(X_{m} \neq i \mid X_{m-1}=i\right)= \\
& =P_{i i}^{m-1}\left(1-P_{i i}\right)
\end{aligned}
$$

Thus, knowing the probabilities of uninterrupted stay in each drought class $i$ during $m$ months $(m=1,2, k \ldots)$, the expected residence time in any class $i, \mathrm{E}\left(T_{\mathrm{i}} \mid X_{0}\right)$, is computed as:

$$
\mathrm{E}\left(T_{i} \mid X_{0}\right)=\sum_{k} k P\left(m=k \mid X_{0}=i\right)
$$

The average time period taken by the process to move for the first time from some initial class $i$ to another class $j, t_{\mathrm{ij}}$, that is called the expected first passage time, is the unique solution of the system of linear equations

$$
t_{i j}=1+\sum_{k \neq j} P_{i k} t_{k j} \forall i, j \in S
$$

The short-term drought class predictions are based on a conditional prediction scheme consisting of the probabilistic evaluation of all the possible paths from the present state $i$ at time point $\mathrm{t}\left(X_{\mathrm{t}}=i\right)$ to any future state $j$ to occur $m$ months later $\left(X_{\mathrm{t}+m}=j\right)$. Adopting the homogeneous formulation to estimate the most probable class 1, 2 or 3 months ahead of the present state, the following probabilities are computed:

$$
\begin{gathered}
P\left(X_{\mathrm{t}+1}=j \mid X_{\mathrm{t}}=i\right) \\
P\left(X_{\mathrm{t}+2}=j \mid X_{\mathrm{t}}=i\right)=\sum_{\forall k \in S} P\left(X_{\mathrm{t}+2}=j \mid X_{\mathrm{t}+1}=k\right) \cdot P\left(X_{\mathrm{t}+1}=k \mid X_{\mathrm{t}}=i\right) \\
P\left(X_{\mathrm{t}+3}=j \mid X_{\mathrm{t}}=i\right)= \\
=\sum_{\forall l \in S} \sum_{\forall k \in S} P\left(X_{\mathrm{t}+3}=j \mid X_{\mathrm{t}+2}=l\right) \cdot P\left(X_{\mathrm{t}+2}=l \mid X_{\mathrm{t}+1}=k\right) \cdot P\left(X_{\mathrm{t}+1}=k \mid X_{\mathrm{t}}=i\right)
\end{gathered}
$$

The predicted drought class $m$-months ahead is the one that presents the higher probability

$$
P\left(X_{\mathrm{t}+m} \mid X_{\mathrm{t}}=i\right)
$$

In the non-homogeneous formulation, 12 monthly transition probability matrices $\boldsymbol{P}^{(\text {month })}$ are considered because the transition probability from state $i$ to state $j$ at time $\mathrm{t}$ depends on the month, thus:

$$
P_{i j}^{(\mathrm{t}, \mathrm{t}+1)}=P\left(X_{\mathrm{t}+1}=j \mid X_{\mathrm{t}}=i\right), \forall i, j \in S
$$


The monthly steady-state probability vectors $\pi^{(\text {Month })}$ are the identical rows of a stochastic matrix (Isaacson and Madsen 1976) computed from the successive product of the monthly transition probability matrices, e.g., for October $\pi^{(\mathrm{Oct})}$ is one of the identical rows of the stochastic matrix $\Theta^{(\mathrm{Oct}, \infty)}$ obtained by:

$$
\Theta^{(\mathrm{Oct}, \infty)}=\left\{P^{(\mathrm{Oct})} P^{(\mathrm{Nov})} \cdots P^{(\mathrm{Aug})} P^{(\mathrm{Sep})}\right\} \cdot\left\{P^{(\mathrm{Oct})} P^{(\mathrm{Nov})} \cdots P^{(\text {Aug })} P^{(\mathrm{Sep})}\right\} \cdots
$$

\section{References}

Anderson TW, Goodman LA (1957) Statistical inference about Markov chains. Ann Math Stat 28:89-110

Bickenbach F, Bode E (2003) Evaluating the Markov property in studies of economic convergence. Int Reg Sci Rev 26(3):363-392

Bishop YMM, Fienberg SE, Holland PW (1975) Discrete multivariate analysis: theory and practice. MIT Press, Cambridge, MA, p 557

Bonaccorso B, Bordi I, Cancelliere A, Rossi G, Sutera A (2003) Spatial variability of drought: an analysis of the SPI in Sicily. Water Resour Manage 17(4):273-296

Buchanan-Smith M (2000) Role of early warning systems in decision making processes. In: Wilhite DA, Sivakumar MVK, Wood DA (eds) Early warning systems for drought preparedness and drought management (Proc. Expert Group Meeting. Lisbon, September 5-7). World Meteorological Organization, Geneva, pp 22-31

Cancelliere Salas AJ (2004) Drought length properties for periodic-stochastic hydrologic data. Water Resour Res 40(2):W02503

Cancelliere A, Rossi G, Ancarani A (1996). Use of Palmer Index as Drought Indicator in Mediterranean Regions. In: Proceedings of the IAHR Congress on From Flood to Drought, Sun City, South Africa, August 5-7, pp 1-25

Cinlar E (1975) Introduction to stochastic processes. Prentice-Hall, New Jersey, p 402

Cordery I (1999) Long range forecasting of low rainfall. Int J Climatol 19(5):463-470

Cordery I, McCall M (2000) A model for forecasting drought from teleconnections. Water Resour Res $36: 763-768$

Isaacson DL, Madsen R (1976) Markov chains: theory and applications. John Wiley, New York, p 267

Karl T, Quinlan F, Ezell DS (1987) Drought termination and amelioration: its climatological probability. J Clim Appl Meteorol 26:1198-1209

Kim TW, Valdés JB, Nijssen B, Roncayolo D (2006) Quantification of linkages between large-scale climatic patterns and precipitation in the Colorado River Basin. J Hydrol 321:173-186

Lloyd-Hughes B (2002) Long-range predictability of European drought. Geophys Res Abstr 5:09474

Lohani VK, Loganathan GV (1997) An early warning system for drought management using the Palmer drought index. J Am Water Resour Assoc 33(6):1375-1386

Lohani VK, Loganathan GV, Mostaghimi S (1998) Long-term analysis and short-term forecasting of dry spells by the Palmer drought severity index. Nord Hydrol 29(1):21-40

McKee TB Doesken NJ, Kleist J (1993) The relationship of drought frequency and duration to time scales. In: 8th Conference on Applied Climatology. Am Meteor Soc, Boston, pp 179-184

McKee TB, Doesken NJ, Kleist J (1995) Drought monitoring with multiple time scales. In: 9th Conference on Applied Climatology, Am Meteor Soc, Boston, pp 233-236

Moreira EE, Paulo AA, Pereira LS, Mexia JT (2006) Analysis of SPI drought class transitions using loglinear models. J Hydrol 331:349-359

NDMC (2006) What is drought? National Drought Mitigation Center (http://drought.unl.edu/whatis/what.htm)

NSSTC (2003) NASA working to take the guesswork out of long-term drought prediction (http://www.msfc.nasa. gov/news/NSSTC/news/releases/2003/N03-008.html)

Paulo AA, Pereira LS (2006) Drought concepts and characterization. Comparing drought indices. Water Int $31: 37-49$ 
Paulo AA, Pereira LS (2007) Prediction of SPI drought class transitions using Markov chains. Water Resour Manage 21:1813-1827

Paulo AA, Pereira LS, Matias PG (2003) Analysis of local and regional droughts in southern Portugal using the theory of runs and the Standardized Precipitation Index. In: Rossi G, Cancelliere A, Pereira LS, Oweis T, Shatanawi M, Zairi A (eds) Tools for drought mitigation in mediterranean regions. Kluwer, Dordrecht, pp 55-78

Paulo AA, Ferreira E, Coelho C, Pereira LS (2005) Drought class transition analysis through Markov and Loglinear models, an approach to early warning. Agric Water Manag 77:59-81

Rossi G (2003) Requisites for a drought watch system. In: Rossi G, Cancellieri A, Pereira LS, Oweis T, Shatanawi M, Zairi A (eds) Tools for drought mitigation mediterranean regions. Kluwer, Dordrecht, pp $147-157$

Santos JA, Corte-Real J, Leite SM (2005) Weather regimes and their connection to the winter rainfall in Portugal. Int J Climatol 25(1):33-50

Santos J, Corte-Real J, Leite S (2007) Atmospheric large-scale dynamics during the 2004/2005 winter drought in Portugal. Int J Climatol 27(5):571-586

Sivakumar MVK, Wilhite DA (2002) Drought preparedness and drought management. In: Drought Mitigation and Prevention of Land Desertification (Proc. Intern. Conf., Bled, Slovenia), UNESCO and Slovenian Nat. Com. ICID, Ljubljana, CD-ROM paper 2

Steinemann AC (2003) Drought indicators and triggers: a stochastic approach to evaluation. J Am Water Resour Assoc 39(5):1217-1233

Steinemann AC (2006) Using climate forecasts for drought management. J Appl Meteorol Climatol 45 (10):1353-1361

Tadesse T, Wilhite DA, Hayes MJ, Harms SK, Goddard S (2005) Discovering associations between climatic and oceanic parameters to monitor drought in Nebraska using data-mining techniques. J Climate 18 (10):1541-1550

Trigo RM, Vázquez DP, Osborn TJ, Diéz YC, Fortis SG, Parra MJ (2004) North Atlantic Oscillation influence on precipitation, river flow and water resources in the Iberian Peninsula. Int J Climatol 24:925-944

Tsakiris G, Vangelis H (2004) Towards a drought watch system based on spatial SPI. Water Resour Manage 18(1):1-12

Vicente-Serrano SM (2006) Differences in spatial patterns of drought on different time scales: an analysis of the Iberian Peninsula. Water Resour Manage 20(1):37-60

Wedgbrow CS, Wilby RL, Fox HR, O'Hare, G (2002) Prospects for seasonal forecasting of summer drought and low river flow anomalies in England and Wales. Int J Climatol 22(2):219-236

Wilks DS (1995) Statistical methods in the atmospheric sciences. International Geophysics Series, vol. 59. Academic, New York, p 464 